\title{
CXCL6 wt Allele
}

National Cancer Institute

\section{Source}

National Cancer Institute. CXCL6 wt Allele. NCI Thesaurus. Code C49768.

Human CXCL6 wild-type allele is located within $4 \mathrm{q} 21$ and is approximately $2 \mathrm{~kb}$ in length.

This allele, which encodes C-X-C motif chemokine 6 protein, is involved in leukocyte trafficking and the mediation of inflammatory responses. 